\title{
Epistemic Subjects, Discursive Selves, and Dialogical Self Theory in the Psychology of Moral and Religious Development: Mapping Gaps and Bridges
}

\author{
James M. Day \& Paulo Jesus
}

To cite this article: James M. Day \& Paulo Jesus (2013) Epistemic Subjects, Discursive Selves, and Dialogical Self Theory in the Psychology of Moral and Religious Development: Mapping Gaps and Bridges, Journal of Constructivist Psychology, 26:2, 137-148, DOI: 10.1080/10720537.2013.759030

To link to this article: https://doi.org/10.1080/10720537.2013.759030

曲 Published online: 08 Mar 2013.

Submit your article to this journal $\longleftarrow$

Џ Article views: 200

4 Citing articles: 7 View citing articles 저 


\title{
SPECIAL SECTION
}

\section{Epistemic Subjects, Discursive Selves, and Dialogical Self Theory in the Psychology of Moral and Religious Development: Mapping Gaps and Bridges}

\author{
James M. Day \\ Université catholique de Louvain, Belgium \\ Paulo Jesus \\ Psychology Department of Infante D. Henrique Portucalense University, Porto, Portugal, \\ and Philosophy Center, Lisbon University, Lisbon, Portugal
}

\begin{abstract}
This article charts various communalities and differences between cognitive-developmental and sociocultural models in the psychology of moral and religious development, with particular attention to Hubert Hermans's model of the dialogical self. The authors propose that, despite marked differences, even oppositions, between conceptual models and visions of the human subject in these two ways of conceiving psychological functioning, the cognitive-developmental approach and the narrativedialogical approach show meaningful correlations and overlap. Arguing for a "meta-dialogical" perspective benefiting from both cognitive-developmental and dialogical self contributions, the article goes on to explore some implications for moral and religious education.
\end{abstract}

\section{INTRODUCTION}

For some years we have been concerned with conceptual and empirical relationships between cognitive-developmental and discursive approaches to thinking about human psychological functioning, especially as these pertain to the psychology of moral decision making and moral development, and the psychology of religious experience, conceptions of religious "belief," and questions concerning religious, faith, and spiritual development (see, e.g., Day, 1991, 1993, 1994,

Received 22 January 2012; accepted 23 January 2012.

Address correxpondence to James M. Day, Université catholique de Louvain, Faculty of Psychology and Education, Place Cardinal Mercier, 10, 1348 Louvain-la-Neuve, Belgium. E-mail: James.day@uclouvain.be 
2000, 2001, 2002, 2007a, 2007b, 2008a, 2008b, 2009, 2010a, 2010b, 2010c, 2011; Day \& Naedts, 1997, 2006; Day \& Tappan, 1996; Day \& Youngman, 2003; Jesus, 2011a, 2011b).

Dissatisfied with cognitive-developmental models that in our view neglect questions pertaining to context, affect, and "embodiment," we have been drawn to the research of discursive thinkers and constructionists, in which the work of Hubert Hermans on the dialogical self emerges as a distinctive and profound attempt to reconcile the movement of cultural meaning formations with the structuring process of selfhood. In this article, we build on recent work at the interface of cognitive-developmental and discursive, socio-cultural approaches, in the psychology of moral and religious development, retracing their basic theoretical components. We then go on to address what we consider as the particular contribution of dialogical self theory, as Hermans and HermansKonopka (2010) conceived of it, especially their notion of positioning, before entertaining some considerations for the importance of this contribution for moral and religious education.

\section{EPISTEMIC SUBJECTS: COGNITIVE-DEVELOPMENTAL CONCEPTIONS OF PSYCHOLOGICAL FUNCTIONING AND OF MORAL AND RELIGIOUS DEVELOPMENT}

Piaget's concerns as to how and whether advances in other domains of cognitive functioning, such as mathematical and logical reasoning, would stimulate similar, or at least correlated, transformations in thinking about religion, have had a significant impact on psychological science and have defined a clearly established place in the psychology of religion and especially the psychology of religious and spiritual development as a specific, recognized domain of inquiry, with sound empirical testing and valid results (Day, 2007a, 2008a, 2010b, 2011; Paloutzian \& Park, 2005; Spilka, Hood, Hunsberger, \& Gorsuch, 2003; Zinnbauer \& Pargament, 2005). The impact of Piaget's concepts and methods on the psychology of religion can also be seen from the time of Goldman (1964) to recent research trends inspired by Goldman's operationalization of Piaget's own questions (Spilka et al., 2003; Tamminen \& Nurmi, 1995), as well as in current models of faith development (Day, 2007a, 2007b, 2008a, 2010b, 2011; Day \& Youngman, 2003; Fowler 1981, 1987, 1996; Fowler \& Dell, 2006; Streib, 1997; Streib et al., 2009), religious judgment development (Day, 2010c; Oser \& Gmunder, 1991; Oser \& Reich, 1996; Oser, Scarlett, \& Buchner, 2006; Reich, Oser, \& Scarlett, 1999), and in the model of hierarchical complexity (MHC; Day, Commons, Ost, \& Bett, 2007). Contributions using the MHC have corrected for empirical problems in Piaget's work and in neo-Piagetian models, including those in the domains of faith development and religious judgment development. This work has demonstrated, with the help of Rasch-Analysis, the existence of stages of complexity in religious cognition and postformal stages (Commons \& Richards, 2003), showing also their relationships to stages in other domains, such as moral reasoning and reasoning about informed consent. In addition, it has explored the impact of religious elements to moral decision making (Day 2008a, 2009, 2010b, 2011).

These cognitive-developmental approaches, rich in theoretical constructs and with increasing rigor in empirical testing, now offer an impressive record underscoring Piaget's notion of the epistemic subject (1968, p. 58) as fundamentally concerned with meaning structures and, more specifically, the construction of meaning in relationship to questions of life purpose and ultimate values. They have highlighted that religious and spiritual development can indeed be considered 
in psychological terms, illustrating how notions of stage and structure can be applied in the religious domain; offered compelling claims for the existence of universal, invariant sequences and hierarchies in cognitive transformation of religious concepts and spiritual experience; and shown how developments in other domains of cognition, especially the domain of moral judgment development, interact with structural change in thinking about religious issues, concepts, symbols, images, and spiritual experience. In a word, the structural account of cognitive development discloses a robust, deep process of self-organization, relatively independent of content and resistant to shallow modes of critical deconstruction.

\section{COGNITIVE-DEVELOPMENTAL MODELS: PROBLEMS, PROSPECTS, AND ALTERNATIVES}

We have contributed to the literature in the cognitive-developmental domain and also been critical of it, taking seriously those who have questioned the utility of results from cognitivedevelopmental empirical research and those who have claimed the need for alternative and complementary approaches rooted in alternative paradigms. We have, for example, noted the critiques of Goldman and allied researchers who have asserted that Piagetian-oriented models lacked sensitivity to context—namely, religious context and exposure to religious content (Spilka et al., 2003). Furthermore, the concentration on the cognitive development of children and adolescents, to the exclusion of adults, and the lack of longitudinal studies offer an unsatisfactory framework for thinking about religious and spiritual development across the life span and for grasping the semiotic saturation and ideological invention particular to the adult years (Belzen, 2009; Day, 1994, 2008a; Dillon \& Wink, 2002; Popp-Baier, 1997; Ray \& McFadden, 2001; Roukema-Koning, 2005).

There are critiques of Fowler's model of faith development, and of Oser and colleagues' (2006) model of religious judgment development, on epistemological, theoretical, and methodological grounds. Streib (1991, 1997; Streib et al., 2009), Tamminen and Nurmi (1995), and Wulff (1997) have observed that both faith development and religious judgment constructs, along with conceptions of development, suffer from a lack of longitudinal data to support the developmental trajectories proposed, and there is insufficient cross-cultural data to support the notion of universal conceptions of faith and religious judgment. Our own work has shown that assumptions in both faith development and religious judgment models as to supposed relationships between moral judgment development and faith or religious judgment development were at least initially based on meager and sometimes contradictory evidence, and have not always held up in large, empirical investigations of such relationships. We have argued that this may undermine the supposedly distinct and specifically religious character of faith and religious judgment and its supposed difference from the more robust construct of moral judgment development, going so far as to suggest that the basic structural component in faith and religious judgment stages may be moral judgment, with elaborations in religious language, according to the questions and questionnaires used (Day, 2007a, 2008b, 2010a, 2010b, 2011; Day \& Naedts, 2006; Day \& Youngman, 2003).

We have also offered empirical evidence that it may be useful to think of religious and spiritual development in terms of more than one religious voice (Day, 1997, 2001, 2002; Day \& Youngman, 2003), at least somewhat consonant with what has been demonstrated in the domain of moral judgment development (Brown \& Gilligan, 1991; Day \& Youngman, 2003; Gilligan, 1996). This part of our work has linked up with others who have called into question the very notion of 
human beings as univocal subjects, speaking consistently and in linear representation, in the same ways regardless of audience and context. Every subject may display not only multiple voices but also multiple idioms, potentially with very different grammars, to express and justify moral and religious/spiritual options. People speak about moral and religious issues in the moral voices identified by Gilligan as ones of justice (à la Kohlberg) and care, and in religious voices, wherein religion is a matter of principle or, alternatively, of relationship (Day, 1991, 1993, 1994, 2001, 2002, 2009; Day \& Naedts, 1997; Day \& Tappan, 1996; Day \& Youngman, 2003). In keeping with Gilligan's insights and our empirical evidence, these religious voices differ between subjects on the basis of gender and culture. However, they also differ within subjects according to the local audiences and the specific purposes of self-disclosure. The truth of such situated self-enactment lies in the felicity of a performance rather than in the accuracy of a representation (Day, 2001, 2002, 2009, 2011; Jesus, 2011a).

Other researchers-such as Desimpelaere, Sulas, Duriez, and Hutsebaut, (1999), Duriez, Luyten, Corveleyn, and Hutsebaut (2005), Streib (1991, 1997), and Streib and colleagues (2009) - have argued, using contrasting empirical and longitudinal modes of research, that we ought to shift from thinking about religious development in terms of stage to an appreciation of religious orientation and style of religious functioning and speaking, given movement across orientations, with stage progression and regression over time. In sharp contrast with Piagetian orthodoxy, this strand of research demonstrates the existence of multiple stage structures within the same subject when engaged in reflecting on dilemmas and in self-interpretive narration, and therefore renders the notion of sequential order, stage stability, and irreversibility suspect in faith and religious judgment models (see also Day, 2011). Thus, the locus of moral and religious cognition must be placed not in internal self-organizing structures but in the discursive practices wherein our multiple selves emerge dialogically and bodily. In this light one must question both the frames and aims of development in this realm. For the Piagetian assumption of an epigenetic landscape unfolding a continuous increase of autonomy seems to obliterate the primacy of otherness and of socially shared semiotic resources in the process of moral and religious/spiritual self-definition.

\section{LANGUAGE, CONTEXT, NARRATIVE}

Belzen (2009) offered a recent review of the literature on socio-cultural approaches to psychology and to the psychology of faith, religious, and spiritual development that emphasizes, as we have done (e.g., Day, 2002; Day \& Naedts, 2006; Day \& Tappan 1996; Day \& Youngman 2003; Jesus, 2011a), the importance of narrative psychology, both for conceiving human experience and for understanding it as a process of meaning creation.

We move toward a conception of the human subject as an inhabited, decentered actor in a "theatrical" world of virtually infinite possible meanings, stories, and selves, wherein much embodied action is rehearsed, justified, and reviewed according to the narrative possibilities inherent in the actual context(s) in which action occurs. When I think about what to do, I imagine how I will recount a story to others about what I have done, how it would sound to or otherwise be received, understood, and evaluated by them. In line with well-known meta-theoretical accounts of narrative selfhood by P. Ricoeur (1988, 1992), C. Taylor (1989), A. McIntyre (1985), J. Bruner (1990), K. Gergen (1994, 2009), T. Sarbin (1986), D. P. McAdams (1996, 2006), and M. Freeman (1993, 2010), among others, we believe that our cultural mode of construing human agency, which 
emphasizes the display of diachronic self-unity and synchronic self-coherence, makes us learn and value the categories of narrative grammar as the natural ground of selfhood. The existential search for meaning and self-justification coincides with the process of self-constitution through the sociocultural learning of the idiom of selfhood - that is, the relational art of storytelling. And one learns it by doing, by performing with others the plural emplotments of shared episodic memories. The psychological connectedness that defines a person originates precisely in that joint performance. Any case against narrativity (e.g., Strawson, 2008) does not succeed in disentangling the reality of selfhood from a relational and semiotic process; it only highlights the fact of "multi-being," which means, "in the beginning is the relationship" (Gergen, 2009, pp. 29-31, 133-135). It is true that self-phenomenology is not fully reducible to self-hermeneutics, although a fully self-examined life requires the infinite task of so laborious and interminable reduction. Indeed, much experience may be accompanied by a sheer muteness, remaining unspeakable as a brute impersonal lived matter, given that it does not belong to any previous "language game" capable of anchoring it within the logical space of communally intelligible possibilities. Both traumatic experiences and spiritual peak experiences affect deeply the flesh and blood of any storyteller whose body repeatedly remembers them, in vivid and multisensory flashbacks, but finds no semiotic means to articulate the content of that unstoried remembrance. Thus, whenever self-affection encounters the void space of unintelligibility, which means inarticulacy and inability of self-narration, one is confronted with the imperative of coconstructing a new signifier in order to avoid either fragmentation, dissociation, or even utter nonsense. The life-narratives or myth/biographies of the believers nourish themselves by rereading and rewriting texts of epiphanies and kairological turning points in which the bounds of self-storying are expanded. It follows that becoming a spiritual/religious self, experiencing conversion or deconversion, means the performative process of conjoining a chaotic bundle of phenomenological data with a narrative hermeneutic matrix shared by a community of faith and life. When I say what I "believe" I cast myself into the framework of what can be understood by others, through language, so that what occurs is a kind of performative in which I am constantly asking myself, "Who might I become if I were to speak like that?"

In his neo-Piagetian work on the psychology of faith development, James Fowler devotes some attention to narrative but insists too much on the reductive and selective adjustment of autobiographical material to questions of stage and structure, devoting insufficient attention to contextual detail and missing out on features of discourse that would disconfirm stability and progressive movement in stage hierarchical sequence. As Streib and colleagues' (2009) recent research amply demonstrates, such detail emerges, if allowed, in other analyses and longitudinal studies using Fowler's methods, as well as in research in which Fowler's interview methods are complemented by other empirical studies aimed at understanding how people speak of faith, religious involvement, and changes in religious attitude over a large time span, auguring for a more thoroughly narrative and relational creation of selfhood within religious language.

\section{DISCURSIVE, DIALOGICAL, SOCIO-CULTURAL SELVES: CONSTRUING THE DEVELOPMENTAL "GOOD"}

The works of Bakhtin $(1981,1986,1990)$ and elaborations of his thought and method in contemporary psychology by Hermans and Kempen (1993), Tappan (1993, 2001), Day and Tappan, 
(1996), and Wertsch (1991) are instructive in helping us imagine an alternative, socio-cultural model for the psychology of religious and spiritual development that would take the linguistic, narrative, discursive turn we have been describing into account. Bakhtin argued that the human psyche is semiotically and linguistically mediated, and that it originates in the context of social relationships and social interaction. Although Bakhtin's work parallels some of the emphases in Vygotsky's modeling of human development and echoes Vygotsky's assertion that external relationships and discursive processes become "internalized" within the psyche, it succeeds in avoiding a splitting of internal and external that may be inferred in Vygotsky's account. For Bakhtin, the notions of voice and ideological polyphony with polyglotism or heteroglossia redescribe the essence of a character, both in fictional and lived narratives, and invite us to develop new theoretical frameworks and methodological tools. The multiple selves of a person constitute a dynamic space of discursive locations expressing particular appropriations, recombinations, and reconfigurations of the voices that inhabit a social and thus conversational world. How, in this discursive, dialogical, socio-cultural account of selfhood, might we think about religious and spiritual development? What would be the proper objects of study? And how should we construe developmental endpoints, goods, and relative developmental maturity?

Bakhtin's understanding of answerability and authorship offers some clues in this regard, helping us think about "responsivity" as a way of thinking about growth and good in development. Therefore, development entails differentiation, a product of linguistic processes in which the person acquires his or her own voice(s), becomes responsible for answering to others, and thus holds a singular place in his or her communicative world (see Day, 2011; Day \& Tappan, 1996). What develops in this process of differentiation is a capacity for authorship that implies speaking, responding, and contributing to the linguistically funded construction of relationships. Hence, responsivity, accountability, and semiotic novelty develop simultaneously through the transformative vocalization of the voices of others in an emerging storyteller. The process of becoming a person consists in the gradual ownership and appropriation of the words and symbols of others, which presupposes that otherness precedes selfhood and opens up its horizon of possible meanings. A voice becomes one's own only when one populates it with one's own intention; understands oneself as capable of giving to them one's own shape, accent, nuance, tone, gestures; and becomes increasingly aware of the ways this speaking has an impact on others, inviting, defying, promoting, blocking, crafting, and creating with their voices. The authority of others' voices turns into one's own multivocal authorship thanks to a process of selective assimilation and "ideological becoming" (Bakhtin, 1981, p. 348). However, the developmental good is not a matter of producing one's own voice, for there is no "true" or "real" voice of oneself, but instead an emergent capacity to locate the sound and impact of the way one is speaking in relationship to others. The ideal telos of development would be a dialogical community of voices allowing conversation and relationships to continue for the full flourishing or optimal actualization of all concerned. Speaking is always, in this sense, a mutual act, in which questions of location, meaning, and identity remain uncertain and open. How well one operates in this uncertainty, vulnerability, and indeterminacy - whether or not one is able to acknowledge it, participate in it, and understand the communal possibilities carried by that unstable polyphony-becomes the measure of personal and relational developmental good and maturity.

Although this bears resemblance to some features of Piagetian notions of developmental maturity in ways that can be found in Kohlberg, Fowler, and Oser-most notably in the capacity to take the perspective of another in the building of a responsible self-what gets internalized is not only the cognitive mapping of another as distinct from the self but, for Bakhtin and in our 
view, whole conversations, or fragments of them, which continue to live, to echo, and to provoke within the linguistic field of one's very conversational, mind (Day, 2011).

Devising ways for charting this developmental good, and how this maturity looks as it takes shape, is not as neatly given to being measured, in terms of stage and structure, as the cognitivedevelopmental models would assert, for there is a real and nonpejorative sense in which, in this view, we are always making it up as we go along, without a predetermined endpoint. As we move along, we are ideally more able to expand relational possibilities for creative action, and to coconstruct understandings of what communal flourishing would mean. On this point, the conversational notion of supplementation (Gergen, 1994; McNamee \& Gergen, 1999) illustrates the semiotic and dialogical process of "co-creation of everything" (Gergen, 2009, p. 36) through the fruitful coordination of utterances and actions.

How might this apply to religious and spiritual development? In this domain, we should consider social competence within discourse practices as a key feature of developmental good-that is, as the capacity to contribute to and expand possibilities for imagining the world in religious and spiritual terms and for evaluating, mutually, how such constructions bear on relationships and promote the practical welfare of people and living environments. The developing person would have increasing competence in building, holding, and inviting conversation about matters pertinent to religious belief and practice that would lead to novel and broader ways of becoming and being religious/spiritual.

Our research has demonstrated that notions such as distinctive voices and discursive frames can be empirically verified in studies of how people talk about religion and religious experience. Moreover, some of our experimental studies show that the way people talk about these matters, and about the meaning of "being religious/spiritual," shifts in function of the audience to which the person addresses speech (Day, 2008a, 2008b, 2009, 2011). In this sense, we have become increasingly interested in a psychology of religious and spiritual development that would turn from a concern with structural changes in religious belief as a supposedly "internally" held facet of subjectivity and meaning-making to a consideration of religious elements as a relational resource (see also Gergen, 1993, 2009), and to careful studies of how particular ways of understanding religion and spirituality affect the making of hypothetical and, crucially, real-life decisions that bear on relationships (Day, 1993, 1994, 1999, 2002; 2009; 2010a; Day \& Naedts, 1997, 2006; Day \& Youngman, 2003). Instead of thinking exclusively about stage and structure within individuals, we then ask how uses of religious discourse affect the ways in which people make more or less room for the mutual construction of meaning, purpose, and opportunity within relationships.

\section{DIALOGICAL SELF THEORY: THE TELEOLOGICAL DYNAMICS OF POSITIONING}

Dialogical self theory (DST) contributes to the dismantling of "realist" or "correspondence" practices in psychological science. Owing in part to its self-avowed roots in the work of George H. Mead, William James, and in M. Bakhtin, DST participates in a fundamental shift in philosophical assumptions about what psychological science can do. By its insistence that all knowledge - including knowledge of ourselves, others, and the world-is constructed through and thus epistemologically constrained by the limits of language and relationship, DST participates in this regrounding of psychological reality in semiotic and relational processes rather than in assertions about "how things really are" in themselves (supposedly outside of language). 
This does not mean, however, that DST has abandoned efforts to bring empirical rigor to such observations, or that it would accept just any characterization of self-functioning as convincing. And it is through reports of close clinical observation and empirical studies, including naturalistic and laboratory studies, that Hermans and Hermans-Konopka (2010) and others within the DST framework developed their most compelling construct-namely, the concept of positioning. By positioning, they mean the physical and emotional coordination of relationships through which we come to know ourselves, others, and the world, in terms of a series of increasingly identifiable positions, with vocal resonance and emotional valence. These positions become useful as a vocabulary for talking about human functioning through ritualized, dialogical, interactions in which the interpersonal and intrapersonal conjoin to form a set or relatively stable positions and changing forms of positioning that can be identified in the self and related to patterns of ongoing interaction with others. This process shapes not only how we know ourselves and others but also how we feel about ourselves and them, and establishes probabilities that can be charted in how we are likely to act. It is part of the genius of DST to have shown how physical positioning, embodied vocalizing, and emotion in dialogical interaction may shape internal dialogical worlds as well as interpersonal worlds and relationships (Cooper \& Hermans, 2007; Hermans \& HermansKonopka, 2010, p. 226). Over time, a set of positions-namely, I-position, third-position, metaposition, promoter-position, and coalitions of positions-characterizes how people dialogue with themselves and with others, whether imaginary or real, as they move through life (Hermans \& Hermans-Konopka, 2010).

Hermans and Hermans-Konopka (2010, pp. 191, 228ff) observed that, for optimal development to occur, a person needs to acquire dialogical competencies that allow him or her to move from mere concerns with continuity and self-coherence in I-positions toward a meta-position that produces a kind of metadialogical and metacognitive awareness - that is, an understanding of his or her own dialogical processes, comprising the dynamic architecture of coalitions of positions and the catalytic efficacy of promoter positions. Thus, positioning plasticity, openness to genuine alterity, and access to ever higher-order reflexivity are privileged as developmental goods and as the touchstone of developmental trajectories.

This is particularly evident in the case of promoter-positions, given their value as "innovators of the self," generators of novelty, and inducers of motion through wider possibilities of meaning that enrich, morally and spiritually, sensitive relationships. Promoter positions in the self and in dialogue with others augur for greater openness toward the future, and help the person integrate a vaster diversity of self-definitions and a broader band of "selves" within others (Hermans \& Hermans-Konopka, 2010, p. 228). Furthermore, because of their central role amid the dialoguing voices in the mind as at once a self-unifying and self-innovating force, promoter-positions "have the potential to reorganize the self towards a higher level of development" (Hermans \& Hermans-Konopka, 2010, p. 232) and to manage the balance between continuity and discontinuity. Strengthening the case for the value of promoter-positions in creating meaningful order and direction in the (too often chaotic) multiplicity of self-positions, Hermans and HermansKonopka (2010) provided examples of how methods stressing both support and gentle-yet-clear confrontation of dominant self-positions can help one establish or reinforce promoter functions and hence develop greater understanding and engaged acceptance of seemingly contradictory and vulnerable features of one's own and others' lived experiences.

Although Hermans and Hermans-Konopka (2010) and others in the DST literature argue against developmental conceptions they regard as too inflexibly structural and sequentially prescriptive, and insist that we should imagine people revisiting earlier self-postures, positions, 
dialogues, narrative scripts, and relational patterns as they explore alternative ones and develop enhanced discursive competence and resources, it turns out that their outline of the value of promoter-positions and how to help people attain to their strengthening in self and relationship strongly resembles the kinds of developmental goods, or endpoints, suggested by authors from the cognitive-developmental circle. In fact, if one considers Kohlberg's later stages in moral judgment development; or Fowler's and Oser's higher stages in faith and religious judgment development; or postformal stages in the MHC applied to moral and religious judgment development; or the kinds of goals proposed by Day, Gergen, Tappan, and others in narrative approaches to moral and religious development, one finds a common construal of the ideal, final good of development, which appears to be fully consonant with DST's valuation of meta-positioning (or meta-dialogical self-positioning). Such developmental good is conceived of as the capacity for highly sensitive, decentered, and articulate role-taking; in other words, a capacity to regard oneself, others, and complex situations from a larger number of points of view, a tolerant and engaged type of coping with cognitive ambiguity and emotional ambivalence. Otherwise put, translating it into DST's lexicon, this "good" amounts to the ability to adaptively move between I-positions and to achieve self-creativity thanks to a multiverse of meaning liberated by promoter-positions that foster the free composition of identities. Therefore, the meta-position evokes the postformal level of the cognitive-development model in the sense that it surpasses the binary logic of true and false and attains the very fabric of all possible utterances, envisioning contradiction as a pathway to metacognitive complexity and "dialogical authenticity" (Hermans \& Hermans-Konopka, 2010, p. 277). In addition, the fulfillment of a metaposition encompasses the full awareness (be it implicit or explicit) of the dialogical landscape of meaningful possibilities, and that awareness includes a fine sense of the performative character of language and of the socio-symbolic nature of selfhood as the production of speech acts embedded in a particular ecology. Hence, both a postformal moral reasoning and a meta-positioning self consist essentially in grasping the ontological relativity of the semiotic materials that frame the very fluid substance of intelligence and selfhood. Reality appears then as a determined phenomenological possibility in the midst of logically unbounded multi-being.

\section{MORAL AND RELIGIOUS EDUCATION: BETWEEN STRUCTURES AND VOICES}

From a teleological perspective there is an evident commonality between the two models under scrutiny. However, from a dynamic and mechanic standpoint one must underscore a sharp contrast. Indeed, the explanatory model based on the articulation between stage and structure postulates an endogenous force serving the developmental function of "majoring equilibration" (Piaget, 1975), which expresses an internal bio-cognitive, autopoietic necessity. In contrast, the process of dialogical development relies on the sui generis semiotic transformative force of promoterpositions that open and configure a space of polyphonic possibilities and relational, dramaturgical imaginings. In both cases there is a structural element that increases in complexity through the effort to resolve a qualitative discontinuity or an ideological dissonance. It follows that moral and religious education, conceived in accordance with the first model, should foster cognitive development by means of exposing the epistemic subjects to socio-cognitive conflicts that supply an optimal mismatch between assimilation and accommodation, whose efficacy depends on the internal readiness (structural-cognitive maturity) to proceed to an endogenous reconstruction 
of external matter. Education is here nothing but a space of self-activity ruled by an internal law of search for the highest necessity; educators can only provide the best resources for that self-formative activity to occur. On the opposite, the dynamics and mechanics of the promoterpositions conceived of as "innovators of the self" show that moral and religious education, once tackled under the angle of DST, requires the audacity of heterodoxy, dissent, and (self-)irony. An educator assumes the role of a promoter-position only when he or she dares to configure ideologically new I-positions and new meaningful trajectories capable of recomposing their apparent incommensurability into a polyphonic order whose harmonic verticality embraces the wholeness of the ultimate issues. In the last analysis, dialogical authenticity meets that sort of wisdom at the confluence of polyphonic metacognition, empathy, and storytelling. To sum up, metadialogical, moral, and religious education would entail the learning of the many languages and voices that speak of good and sacred, as well as the disclosure of the one behind the many, which is not a final holiest word but a movement beyond all possible grammars.

\section{REFERENCES}

Bakhtin, M. (1981). The dialogic imagination. Austin: University of Texas Press.

Bakhtin, M. (1986). Speech genres and other late essays. Austin: University of Texas Press.

Bakhtin, M. (1990). Art and answerability. Austin: University of Texas Press.

Belzen, J. (2009). Towards cultural psychology of religion: Principles, approaches, and applications. Dordrecht: Springer.

Brown, L., \& Gilligan, C. (1991). Listening for voice in narratives of relationship. In M. Tappan \& M. Packer (Eds.), Narrative and storytelling: Implications for understanding moral development (pp. 43-62). San Francisco: JosseyBass.

Bruner, J. (1990). Acts of meaning. Cambridge, MA: Harvard University Press.

Commons, M., \& Richards, F. (2003). Four postformal stages. In J. Demick \& C. Andreoletti (Eds.), The handbook of adult development (pp. 199-220). New York: Plenum.

Cooper, M., \& Hermans, H. J. M. (2007). Honoring self-otherness: Alterity and the intrapersonal. In L. Simão \& J. Valsiner (Eds.), Otherness in question: Labyrinths of the self (pp. 305-315). Greenwich, CT: Information Age.

Day, J. (1991). The moral audience: On the narrative mediation of moral "judgment" and moral "action." In M. Tappan \& M. Packer (Eds.), Narrative and storytelling: Implications for understanding moral development (pp. 27-42). San Francisco: Jossey-Bass.

Day, J. (1993). Speaking of belief: Language, performance, and narrative in the psychology of religion. International Journal for the Psychology of Religion, 3(4), 213-230.

Day, J. (1994). Narratives of "belief" and "unbelief" in young adult accounts of religious experience and moral development. In D. Hutsebaut \& J. Corveleyn (Eds.), Belief and unbelief: Psychological perspectives (pp. 155-173). Amsterdam: Rodopi.

Day, J. (2000). Le discours religieux en contexte: Deux études auprès d'adolescents et de jeunes adultes en Belgique francophone [Religious discourse in context: Two studies with adolescents and young adults in French-speaking Belgium]. In V. Saroglou \& D. Hutsebaut (Eds.), Religion et développement humain: Questions psychologiques (pp. 57-59). Paris: L’Harmattan.

Day, J. (2001). From structuralism to eternity? Re-imagining the psychology of religious development after the cognitivedevelopmental paradigm. International Journal for the Psychology of Religion, 11, 173-183.

Day, J. (2002). Religious development as discursive construction. In C. Hermans, G. Immink, A. de Jong, \& J. van der Lans (Eds.), Social construction and theology (pp. 63-92). Leiden: Brill.

Day, J. (2007a). Moral reasoning, religious reasoning, and their supposed relationships: Paradigms, problems, and prospects. Adult Developments: The Bulletin of the Society for Research in Adult Development, 10(1), 610.

Day, J. (2007b). Personal development. In F. Watts \& E. Gulliford (Eds.), Jesus and psychology: Approaching the gospels psychologically (pp. 116-137). London: Longman.

Day, J. (2008a). Human development and the model of hierarchical complexity: Learning from research in the psychology of moral and religious development. World Futures: The Journal of General Evolution, 65(1-3), 452-467. 
Day, J. (2008b). Marital spirituality throughout the life course-Insights from the psychology of human development. In T. Knieps-Port le Roi \& M. Sandor (Eds.), Companion to marital spirituality (pp. 85-104). Leuven: Peeters.

Day, J. (2009). La (re)conversion religieuse face aux dilemmes moraux: Regard empirique sur base des recherches avec des adolescents et des jeunes adultes chrétiens et musulmans en Angleterre et en Belgique [Religious (re)conversion in face of moral dilemmas: An empirical perspective from research with Christian and Muslim adolescents and young adults in England and Belgium]. In P.-Y. Brandt (Ed.), La conversion religieuse: Approches psychologiques, anthropologiques, et sociologiques (pp. 151-178). Genève: Labor et Fides.

Day, J. (2010a). Conscience: Does religion matter? Empirical studies of religious elements in pro-social behaviour, prejudice, empathy development, and moral decision-making. In W. Koops, D. Brugman, \& A. Sander (Eds.), The structure and development of conscience (pp. 47-68). London: Psychology Press.

Day, J. (2010b). Religion, spirituality, and positive psychology in adulthood: A developmental view. Journal of Adult Development, 17(4), 215-229.

Day, J. (2010c). Culture, psychology, and religion: Critically appraising Belzen's contributions. Journal of Mental Health, Religion, and Culture, 13(4), 329-336.

Day, J. (2011). Believing as if: Postconventional stages, cognitive complexity, and postformal religious constructions. In A. H. Pfaffenberger, P. W. Marko, \& A. Combs (Eds.), The postconventional personality: Assessing, researching, and theorizing higher development (pp. 172-190). Albany, NY: SUNY Press.

Day, J., Commons, M., Ost, C., \& Bett, E. (2007). Can the model of hierarchical complexity assess religious cognition? Findings from initial research efforts. Paper presented at the Society for Research in Adult Development, Boston.

Day, J., \& Naedts, M. (1997). A reader's guide for interpreting texts of religious experience: A hermeneutical approach. In J. A. Belzen (Ed.), Hermeneutical approaches in the psychology of religion (pp. 173-193). Amsterdam: Rodopi.

Day, J., \& Naedts, M. (2006). Religious development. In R. Mosher, D. Youngman, \& J. Day (Eds.), Human development across the lifespan: Educational and psychological applications (pp. 239-264). Westport, CT: Praeger.

Day, J., \& Tappan, M. (1996). The narrative approach to moral development: From the epistemic subject to dialogical selves. Human Development, 39(2), 67-82.

Day, J., \& Youngman, D. (2003). Discursive practices and their interpretation in the psychology of religious development: From constructivist canons to constructionist alternatives. In J. Demick \& C. Andreoletti (Eds.), The handbook of adult development (pp. 509-532). New York: Plenum.

Desimpelaere, P., Sulas, F., Duriez, B., \& Hutsebaut, D. (1999). Psycho-epistemological beliefs and religious beliefs. International Journal for the Psychology of Religion, 9(2), 125-137.

Dillon, P., \& Wink, M. (2002). Spiritual development across the life course: Findings from a longitudinal study. Journal of Adult Development, 9(1), 79-94.

Duriez, B., Luyten, P., Corveleyn, J., \& Hutsebaut, D. (2005). Consequences of a multidimensional approach to religion for the relationship between religiosity and value priorities. International Journal for the Psychology of Religion, 15(2), 123-144.

Fowler, J. (1981). Stages of faith. San Francisco: Harper \& Row.

Fowler, J. (1987). Faith development and pastoral care. Philadelphia: Fortress Press.

Fowler, J. (1996). Faithful change. San Francisco: Harper \& Row.

Fowler, J., \& Dell, M. (2006). Stages of faith from infancy through adolescence: Reflections on three decades of faith development theory. In E. Roehlkepartain, P. King, L. Wagener, \& P. Benson (Eds.), Handbook of spiritual development in childhood and adolescence (pp. 34-44). London: Sage.

Freeman, M. (1993). Rewriting the self: History, memory, narrative. London: Routledge.

Freeman, M. (2010). Hindsight: The promise and peril of looking backward. Oxford: Oxford University Press.

Gergen, K. (1993). Belief as a relational resource. International Journal for the Psychology of Religion, 3(4), 231-235.

Gergen, K. (1994). Relationships and realities: Soundings in social construction. Cambridge, MA: Harvard University Press.

Gergen, K. (2009). Relational being: Beyond self and community. Oxford, UK: Oxford University Press.

Gilligan, C. (1996). In a different voice: Psychological theory and women's development. Cambridge, MA: Harvard University Press.

Goldman, R. (1964). Religious thinking from childhood to adolescence. New York: Seabury.

Hermans, H., \& Hermans-Konopka, A. (2010). Dialogical self theory: Positioning and counter-positioning in a globalizing society. Cambridge, UK: Cambridge University Press.

Hermans, H. J., \& Kempen, H. J. (1993). The dialogical self: Meaning as movement. San Diego: Academic.

Jesus, P. (2011a). Meaning-creation, selfhood and religion: From religious metanarratives to spiritual self-narratives. Estudios de Psicología, 32(1), 131-145. 
Jesus, P. (2011b). Self as unifying process: On the grammar and phenomenology of agency. In P. Stenner (Eds.), Theoretical psychology: Global transformations and challenges (pp. 73-83). Ontario: Captus.

McAdams, D. P. (1996). The stories we live by: Personal myths and the making of the self. New York: Guilford Press.

McAdams, D. P. (2006). The redemptive self: Stories Americans live by. Oxford: Oxford University Press.

McIntyre, A. (1985). After virtue: A study in moral theory. London: Duckworth.

McNamee, S., \& Gergen, K (1999). Relational responsibility: Resources for sustainable dialogue. London: Sage.

Oser, F., \& Gmunder, P. (1991). Religious judgment: A developmental approach. Birmingham, AL: Religious Education Press.

Oser, F., \& Reich, H. (1996). Eingebettet ins Menschein: Beispiel Religion: Aktuelle psychologische studien zur entwicklung von religiosität [Integrated into human being: Religion of example: Contemporary psychological studies on religious development]. Lengerich: Pabst Scientific.

Oser, F., Scarlett, W., \& Buchner, A. (2006). Religious and spiritual development throughout the life span. In W. Damon \& R. Lerner (Eds.), Handbook of child psychology: Theoretical models of human development, vol. 1. Theoretical models of human development (pp. 42-98). New York: Wiley.

Paloutzian, R., \& Park, C. (Eds.) (2005). Handbook of psychology of religion and spirituality. New York: Guilford Press. Piaget, J. (1968). Le structuralisme [Structuralism]. Paris: Puf.

Piaget, J. (1975). L'équilibration des structures cognitives: Problème central du développement [The equilibration of cognitive structures: The central problem of development]. Paris: Puf.

Popp-Baier, U. (1997). Psychology of religion as hermeneutical cultural analysis-Some reflections with reference to Clifford Geertz. In J. Belzen (Ed.), Hermeneutical approaches in psychology of religion (pp. 47-60). Amsterdam: Rodopi.

Ray, R., \& McFadden, S. (2001). The web and the quilt: Alternatives to the heroic journey toward spiritual development. Journal of Adult Development, 8(4), 201-211.

Reich, H., Oser, F., \& Scarlett, D. (1999). Psychological studies on spiritual and religious development: Being human, vol. 2. The case of religion. Lengerich: Pabst Science.

Ricoeur, P. (1988). Time and narrative (3 vols.). Chicago: University of Chicago Press.

Ricoeur, P. (1992). Oneself as another. Chicago: University of Chicago Press.

Roukema-Koning, B. (2005). Als mannen en vrowen bidden: Een empirisch-psychologisch studie [Ways men and women pray: An empirical, psychological, study]. Kampen: Boekencentrum.

Sarbin, T. (1986). The narrative as root metaphor for psychology. In T. Sarbin (Ed.), Narrative psychology: The storied nature of human conduct (pp. 3-21). New York: Praeger.

Spilka, B., Hood, R., Hunsberger, B., \& Gorsuch, R. (2003). The psychology of religion: An empirical approach. New York: Guilford.

Strawson, G. (2008). Against narrativity. In G. Strawson (Ed.), Real materialism and other essays (pp. 189-208). Oxford, UK: Oxford University Press.

Streib, H. (1991). Hermeneutics of symbol, metaphor, and narrative in faith development theory. Frankfurt: Peter Lang.

Streib, H. (1997). Religion als stilfrage: Zur revision struktureller differenzieurung von religion in blick auf die analyse der pluralistisch-religionslage der gegenwart [Religion as a style issue: Towards a revision of the structural differentiation of religion in the context of present religious pluralism]. Archiv für Religionpsychologie, 22, 48-69.

Streib, H., Hood, R., Keller, B., Csoff, R.-M., \& Silver, C. (2009). Deconversion: Qualitative and quantitative results from cross-cultural research in Germany and the United States of America. Göttingen: Vandenhoeck \& Ruprecht.

Tamminen, K., \& Nurmi, K. (1995). Developmental theory and religious experience. In R. Hood, Jr. (Ed.), Handbook of religious experience (pp. 212-230). Birmingham, AL: Religious Education Press.

Tappan, M. (1993). Relational voices and moral development: Reflections on change. In P. Kahaney, L. Perry, \& J. Janangelo (Eds.), Theoretical and critical perspectives on teacher change. Norwood, NJ: Ablex.

Tappan, M. (2001). Interpretive psychology: Stories, circles, and understanding lived experience. In D. Tolman \& M. Brydon-Miller (Eds.), From subjects to subjectivities: A handbook of interpretive and participatory research methods. New York: New York University Press.

Taylor, C. (1989). Sources of the self: The making of modern identity. Cambridge, MA: Harvard University Press.

Wertsch, J. (1991). Voices of the mind: A sociocultural approach to mediated action. Cambridge, MA: Harvard University Press.

Wulff, D. (1997). Psychology of religion: Classic and contemporary views. New York: Wiley.

Zinnbauer, B., \& Pargament, K. (2005). Religiousness and spirituality. In R. Paloutzian \& C. Park (Eds.), Handbook of the psychology of religion and spirituality (pp. 21-42). New York: Guilford. 